TOURIST DISTRACTIONS 
This page intentionally left blank 


\section{TOURIST DISTRACTIONS}

TRAVELING AND FEELING

IN TRANSNATIONAL HALLYU CINEMA

YOUNGMIN CHOE

DUKE UNIVERSITY PRESS DURHAM AND LONDON 2016 
(C) 2016 Duke University Press

All rights reserved

Printed in the United States of America on acid-free paper $\infty$

Designed by Amy Ruth Buchanan

Typeset in Minion Pro by Westchester Publishing Services

Library of Congress Cataloging-in-Publication Data

Choe, Youngmin, author.

Tourist distractions : traveling and feeling in transnational

hallyu cinema / Youngmin Choe.

pages $\mathrm{cm}$

Includes bibliographical references and index.

ISBN 978-0-8223-6111-4 (hardcover : alk. paper)

ISBN 978-0-8223-6130-5 (pbk. : alk. paper)

ISBN 978-0-8223-7434-3 (e-book)

1. Motion pictures-Korea (South)-History-21st century.

2. Cultural industries-Korea (South) - History-21st century.

3. Popular culture-Economic aspects-Korea (South). 4. Tourism

in motion pictures. 5. Travel in motion pictures. I. Title.

PN1993.5.K6C4844 2016

$791.43095195-\mathrm{dc2} 2015036266$

A different version of chapter 2 appeared as "Affective Sites: Hur Jin-ho's Cinema and Film-Induced Tourism in Korea," in Asia on Tour: Exploring the Rise of Asian Tourism, ed. Tim Winter, Peggy Teo, and T. C. Chang, 109-26 (New York: Routledge, 2009). An earlier version of chapter 5 was published as "Postmemory DMZ in South Korean Cinema, 1999-2003," Journal of Korean Studies 18.2 (2013): 315-36. Reprinted by permission.

Cover art: Detail from a tour-site marker depicting an image from the film April Snow. Photo by the author. 
FOR MY MOTHER AND FATHER 
This page intentionally left blank 